\title{
AN ACADEMIC EDITION OF A RUSSIAN GOTHIC NOVEL ${ }^{\star}$
}

\author{
Rev. of: Gretch, N. I. (2020). Chernaya zhenshchina [The Black Woman] / \\ ed. by E. V. Markasova. Moscow, Ladomir, Nauka. 668 p.
}

\author{
Maxim Chernyshov \\ Ural Federal University, \\ Yekaterinburg, Russia
}

The book under review is an edition of the novel The Black Woman (1834) by the nineteenth-century Russian writer Nikolai Gretsch, part of the academic series "Literary Monuments". It was prepared for publication by E. V. Markasova: the edition is supported by an extensive scholarly apparatus, including two supplemental texts from the 1830s, two scholarly articles, notes on the text, a chronicle of Gretsch's life and work, a bibliography, and a list of illustrations. The reviewer evaluates the scholarly work of Markasova and her colleagues higher than the artistic quality of the novel itself, which suffers from the imperfections characteristic of early experiments in popular fiction. The reviewer believes that the aesthetic context in which Gretsch's Gothic novel is considered must include not only genre, but also the artistic movements of the epoch, especially Romanticism. The lack of attention to this issue leads to some doubtful and controversial assertions in the notes concerning literary trends in the eighteenth and nineteenth centuries. At the end of the review, the author comes to the conclusion that academic studies are currently experiencing heightened interest in the mystical and irrational in literature.

Keywords: "Literary Monuments", Nikolai Gretsch, nineteenth-century Russian literature, popular fiction, Gothic novel, romanticism

Рецензируемая книга - издание романа русского литератора XIX в. Николая Греча «Черная женщина» (1834) в известной академической серии «Литературные памятники», подготовленное доктором филологических наук из Санкт-Петербурга Е. В. Маркасовой и снабженное обширным научным аппаратом. Этот аппарат включает в себя в качестве дополнений два текста 1830-х гг., а в качестве приложений - две научные статьи, примечания к текстам, хронику жизни и деятельности Греча, библиографию и список иллюстраций. Результаты труда ученых (кроме Е. В. Маркасовой, над при-

* Citation: Chernyshov, M. (2021). An Academic Edition of a Russian Gothic Novel. In Quaestio Rossica. Vol. 9, № 2. P. 753-760. DOI 10.15826/qr.2021.2.607.

Цитирование: Chernyshov M. An Academic Edition of a Russian Gothic Novel // Quaestio Rossica. Vol. 9. 2021. № 2. P. 753-760. DOI 10.15826/qr.2021.2.607.

(c) Chernyshov M., 2021

Quaestio Rossica • Vol. 9 • 2021 • № 2, p. 753-760 
ложениями работали еще два специалиста) рецензент оценивает выше, чем художественное качество самого романа, страдающего недостатками, характерными для ранних образцов массовых жанров беллетристики. Замечания к статьям и примечаниям носят в основном частный характер, за одним исключением. По мнению рецензента, в статье уделено недостаточное внимание тому, чтобы готический роман Греча был вписан не только в жанровый, но и в более широкий эстетический контекст своей эпохи и соотнесен с другими феноменами романтической культуры. Несколько примечаний, затрагивающих вопросы художественных направлений, содержат наиболее спорные и противоречивые суждения. Рецензент вписывает данную книгу в линию изданий «Литературными памятниками» готической литературы и приходит к заключению, что в настоящее время академическая наука переживает стадию повышенного интереса к теме мистического и иррационального в словесности.

Ключевые слова: «Литературные памятники», Николай Греч, русская литература XIX в., массовые жанры, готический роман, романтизм

Nikolai Gretsch's novel The Black Woman (1834), released as part of the "Literary Monuments" series from the Nauka publishing house, belongs to the most popular type of publication in this famous series, where the "monument" is one fairly large work, most often previously unpublished in Russian or difficult to access and accompanied by various additions and appendices. However, in this case, the editors evidently intended to present to the public not so much the novel itself as its author, a well-known conservative writer and journalist.

Nikolai Gretsch was a major figure in the Russian culture of his time: his friendship and business ties with the notorious Faddei Bulgarin and his cooperation with the secret police gave him a dubious reputation. In Soviet times, only his non-fiction works were occasionally published, but The Black Woman was issued twice in collections in the 1990s. So, while the novel is hardly a rarity, an authoritative edition of Gretsch's fiction is obviously necessary.

The novel represents a quite successful example of "formulaic" popular literature. An artfully woven intrigue involving several story lines, each with its own mystery resolved in the finale, a mystical motif built on the theme of animal magnetism popular at the time - the book has all the components of a bestseller from the first half of the nineteenth century.

For today's reader, however, the novel's shortcomings are obvious, and they are hardly compensated for by the charm of time. The abundance of coincidences and happy accidents necessary to reveal numerous secrets exceeds any measure of plausibility. The characters, especially the negative ones, reach the level of the grotesque. The novel is overloaded with religious and patriotic ideology: passages similar to the following are constantly and obsessively repeated, filled with servile pathos and mawkish rhetoric: "May God preserve in your people this meekness to the vanquished, this 
devotion to the sovereign and the Fatherland - and Russia will rise above all the kingdoms of Europe, mired now in calamities and crimes generated by forgetting the laws of God!" [Греч, c. 140]. In this regard, it seems surprising both that Gretsch occasionally fell into disgrace for suspected unreliability and that the novel contains depictions of corruption in imperial Russia.

Yet such shortcomings not only do not hinder academic interest, but in some ways stimulate it. The scholarly apparatus provided for this edition is more extensive and diverse than might be expected. The supplements section includes a review of the novel by Osip Senkovsky and a seldom published novella by Prosper Mérimée. This section is multipart. It opens with the article "Journalist, Philologist, Teacher Nikolai Gretsch and his novel The Black Woman", which was co-authored by A. Reitblat, a literary critic and cultural sociologist, E. Markasova, a specialist in popular literature from the eighteenth and nineteenth centuries, and V. Koshelev, a linguist and a historian of nineteenth-century classical Russian literature. This is followed by Markasova's article "The Black Woman: Character Prototypes", her notes on the novel, "A Brief Chronicle of the Life and Activities of Nikolai Ivanovich Gretsch" (compiled by Markasova and Reitblat), a list of abbreviations (in fact a detailed bibliography), and a list of illustrations.

Osip Senkovsky's article "The Black Woman and Animal Magnetism: Concerning the Novel The Black Woman by N. Gretsch, 1834" offers a fragment of a review of the novel published in the magazine Biblioteka dlya chteniya (The Reader's Library). The fragment contains such a capacious characterisation of the novel that Koshelev starts from it in his arguments about poetics. However, the main part of Senkovsky's text is a detailed scholarly description of "animal magnetism", which was widespread in the public consciousness and literature of the time and on which the idea and plot of Gretsch's novel are based. So, this text is particularly useful for understanding the cultural background of the era.

The second supplement to the novel is Prosper Mérimée's novella The Vision of Charles XI, King of Sweden, whose pseudo-historical plot is retold in one of The Black Woman's episodes. The novella is presented in an authentic Russian translation from 1833.

The first section of the article "Journalist, Philologist, Teacher Nikolai Gretsch and his novel The Black Woman", written mainly by Reitblat, renders a detailed account of Gretsch's life and various activities. Markasova is the author of an extensive section representing Gretsch as a linguist who had his own concept of Russian grammar and its teaching. In the same section there is a brief description of Gretsch's second (chronologically first) novel, A Trip to Germany.

In the article's second section, written by Koshelev, The Black Woman is analyzed in detail. It presents a general overview of the literature of the first half of the 1830s, one which is saturated with new insights. Perhaps the author should not have limited himself to listing only Russian books: the fact that Mérimée's novella is reflected in The Black Woman indicates the relevance of contemporary European literature for understanding the novel. 
Koshelev then analyzes The Black Woman's rich genre content. The novel includes elements of a traditional fairy tale, a historical novel, a family novel (all nominations are defined in relation to the context), and, taking into account the "esoteric component", the unconventional genre of the "metaphysical novel". The reader who has already gotten through the story is reminded of the main elements of its plot, with analytical comments explaining the peculiarities of its topics, autobiographical and historical content (in great detail), symbolism (primarily color), language, and characters. The critic then returns to the problem of the genre to dwell on the tradition with the novel is primarily associated, that of the Gothic novel. Neglecting the very first examples of the genre in the 1760s, Koshelev briefly characterizes the works of Anna Radcliffe, popular in Russia, although he also notes that "Gretsch was influenced not so much by the English Gothic novel as by the German (C. H. Spiess, C. A. Vulpius, H. Zschokke, A. Lafontaine and others)" [Греч, c. 423]: Gretsch was fluent in German (and French), but not English. Regrettably, the differences between the English and German types of the Gothic novel are not spelled out, and the detailed description of the differences in Gretsch's approach to the Gothic tradition leaves it unclear whether these differences correspond to the specifics of the German tradition in comparison with the English one or separate the author's approach from the German one. Then Koshelev again turns to the novel's "metaphysical" content and describes in detail the character of Alimari, who is the main popularizer of this worldview, claiming it to be scientific. In the final part of the article, Koshelev returns to the perception of the novel by its contemporaries and offers a very interesting analysis comparing The Black Woman with Pushkin's story The Queen of Spades, which was written at the same time, published in the same year, and is undoubtedly similar to it typologically.

No doubt of high quality, Koshelev's work reflects almost all possible ways of studying the novel. But it still seems to lack one quite fundamental perspective: the novel is not fitted into the context of the artistic systems, trends, and movements of the time. It would be very useful to consider this because the first half of the 1830s, when the novel was written, was a borderline era: Romanticism was still quite lively and topical, at least in France and Russia, but at the same time books founded on a new aesthetic, later called realistic, were already appearing en masse. The latter, however, in our case is relevant only in the sense that the desire to explain unusual phenomena by natural causes corresponds to the ideology of the emerging philosophy of positivism. However, the fact that nineteenth-century literary Gothic was part of the heritage of Romanticism is too well known to be neglected. In some places, Koshelev mentions the Romantics as the primary sources of the fascination with the miraculous and mystical, but he does so casually, without emphasis. Greater attention to this part of the literary process would enrich the article and provide additional incentive to search for some analogies in Markasova's notes. 
The extensive abstract at the end of the book presents this "amazing" novel as "one of the outstanding phenomena of the Pushkin era. Grandiose in design, the novel covers three decades of Russian life at the turn of two great centuries and, following Eugene Onegin, deserves to be called an "encyclopedia of Russian life"' [Греч, c. 667]. Although the analogy with Pushkin's novel in verse may not be quite appropriate, the reason for it is not in doubt: the work of Gretsch incorporates a huge range of cultural realities from the late eighteenth and early nineteenth centuries, requiring extensive commentary for today's reader. It is good, then, that Markasova's notes are astonishing in terms of their immensity and detail.

The article "The Black Woman: Character Prototypes", which is much broader in scope than the title implies, thoroughly describes the creation, publication, and perception of this novel and gives an overview of the facts used in it. But the main part of the article deals with the prototypes of the novel's numerous characters, not only the obvious ones revealed by the author, but also hypothetical ones, indicating the researcher's deep immersion in the chronological context.

The first part of the notes section is devoted to textual issues. The novel's text is reproduced from the first edition of 1834: Markasova carefully studies and analyzes the author's corrections in the 1838 and 1855 editions and the discrepancies they introduce. The list of these takes up 60 pages (447-506), $9 \%$ of the book's total. Gretsch's later edits are not only scrupulously recorded, but also linguistically classified, and sometimes interesting conclusions are made about the development of literary Russian in the middle of the nineteenth century. We are not aware of any precedents to such work in publications of fiction.

The notes on the novel and the supplements occupy 83 pages (506$588), 12 \%$ of the book. In the introduction to this section, the author declares her intention to "cover all the realities, the knowledge of which enriches the understanding of the text. The term 'reality' is understood broadly: it is an object, a fact, an event, and also a word as a unit of language" [Греч, с. 506]. Most of these realities are singled out and explained meticulously. But the stated orientation towards completeness generates high expectations, and sometimes readers will be disappointed. For example, the linguistic comments are very interesting and useful - in particular, the explanations of archaisms and other unusual uses of words and expressions. More rarely, in addition to explaining their meaning (usually comprehensible without explanation), other examples of their use in the literature are given, indicating their prevalence in the epoch. Thus, in the commentary on the ironic meaning of the word "рацея" (exhortation), an example is given from an 1835 story by Zagoskin [Греч, c. 510]. But, for the most part, the commentator does without this. For instance, the note on the remark "она зубы делает" (literally "she makes teeth") is limited to the following: "This means that the child is teething" [Греч, с. 519]. The reader can guess this for themselves; it would be much more interesting to learn about other uses of this expression and about its 
origin (this example is reminiscent of a calque from French, the cases of which are sometimes explained).

The same applies to non-linguistic realities. There is an excellent cultural commentary on the use of walking sticks in the eighteenth and nineteenth centuries, with examples from Sumarokov, Narezhny, Zagoskin, and other works by Gretsch, but there are no examples about whist, for instance [Греч, c. 510, 515-516].

Gretsch's The Black Woman was written in the early 1830s, but is set in the 1790 s and 1810s. The distance between the time of writing and the time of action is significant enough to interpret the novel as historical. To adequately understand the author's intention, it is necessary to know whether he and its first readers perceived the numerous realities mentioned in the novel as outdated signs of the past, as markers of historical flavor. But such notes appear only occasionally. Even today, every reader will understand from the context that a "гривняга" (grivnyaga) is a "гривенник" (grivennik), a ten-kopeck coin. In the commentary only the denomination of this coin is indicated [Греч, с. 541]: it would have been much more useful to inform the reader about its purchasing power both when the plot takes place and in the year of the novel's publication. This would allow us to correlate it with the salary of the soldier who sets this price for a fortuneteller's prediction.

There are also gaps in the notes that can mislead the reader. The French National Guard is stated to have existed until 1827 [Греч, c. 535]. However, to understand a novel from 1834, it is essential to remember that this military unit was recreated after the July Revolution of 1830 .

One linguistic comment is really perplexing. Alimari, one of the central characters, explaining his origin and reasons for appearing in Russia, refers to the fact that his mother was a Morlak Slav. The commentary is as follows: "The Morlaki are an ethnographic group of Eastern Romanesque origin, occupying the mountainous regions in the west of the Balkan Peninsula and adhering to a patriarchal lifestyle" [Греч, с. 549]. However, the area of settlement of the Morlaks and their way of life are not important for the novel, whereas their language and connection with the Slavs are: but nothing is said about this, and the mention of their Romanesque origin in this context will be baffling to the layman.

A conceptual discrepancy is caused by the notes on the aesthetic disputes between the protagonist Kemsky and the artist Berilov. Markasova first connects the latter's arguments about the relationship between nature and art with Roger de Piles' The Idea of a Perfect Painter... and gives two quotes from it in the spirit of Berilov's arguments. But in the next note we are surprised to read: "The opposition of nature and art is commonplace in the literature of this period. Berilov's monologues consistently repeat the statements of the Jena Romantics about the superiority of art over nature, about the freedom of the artist, etc." [Греч, с. 537]. First of all, it is not clear what period is meant: the time of this conversation within the novel and the time when the novel was written were radically different in terms of the prevailing aesthetics. The second phrase implies that the 
commentator means the 1790s, when the conversation takes place. But at this point the Jena Circle's aesthetics had not been worked out. Of course, this may be a slight anachronism. But both Berilov's judgments and the quotations from Piles give us no reason to doubt that he expresses classical views rather than Romantic ones. The dates of Piles' life (1635-1709) are given in the previous note - what does he have to do with Romanticism? Berilov is a graduate of the Academy of Arts; the classical academic style rejected the latest trends in painting, starting from the Romantic period until at least the modernist era. It is characteristic that, when arguing her dubious thesis about the Jena Romantics, Markasova does not offer a single quotation from the Schlegel brothers or Novalis, but instead refers to the modern literary critic Markovich ("Romantics do not appeal to ignore reality, but find it necessary to rise above it" [Греч, с. 537]). But "reality" and "nature" are not at all equivalents, especially for the Romantics. Nature is one of the key concepts of Romanticism (unlike classicism). Novalis, the brightest of the Jena Romantics, wrote in his Fragments: "All the properties inherent in ordinary nature are befitting poetry", "nature... is pure poetry" [Литературная теория немецкого романтизма, с. 125, 136]. Rather significant is Markasova's note on one of details mentioned in the novel: "The Aeolian (or air) harp does not require a musician to play: the sounds arise due to the wind blowing, which touches the strings. The image gained popularity in Russian literature under the influence of German and English romanticism" [Греч, с. 554]. Quite correctly describing a characteristic Romantic emblem that emphasizes nature's ability to create beauty without human participation, the commentator does not see here a contradiction with her idea that the Jena Romantics allegedly elevated art over nature. Berilov is certainly not devoid of some Romantic features. But separating the features of different artistic systems in Berilov's mind, as well as in the novel as a whole, demands a more subtle and detailed analysis. These unpersuasive notes makes us regret once again that Romanticism did not attract Koshelev's attention in his article.

More precise analogies with the works of the German Romantics can be seen in The Black Woman. For example, Kemsky's reasoning about meeting soul mates after death is quite consistent with similar ideas expressed by Novalis in Hymns to the Night and Heinrich von Ofterdingen. The novel begins with a discussion of the difference between dream and waking visions, much in the same way as in the second vigil of Hoffmann's The Golden Pot. And Kemsky's story about his early childhood, when from the words of adults about epidemics he imagines the evil sorceress Plague and, driven by curiosity and overcoming fear, goes to the window to look at her, has a possible connection with an episode from Hoffmann's The Sandman, where a student tells a friend how as a child he hid in his father's room to see the terrible fiend from his nanny's fables.

It should be emphasized that the above issues relate to only few notes: most of them match the stringent requirements for scholarly commentary and are of great interest. 
The section "A Brief Chronicle of the Life and Work of Nikolai Ivanovich Gretsch", compiled by Markasova and Reitblat is impressive in terms of size: 32 pages (for comparison, a similar section in the "Literary Monuments" 2019 publication of Nikolai Gnedich's early novel Don Corrado de Guerrera takes up only 5 pages [Гнедич, с. 439-443]).

There is also a very solid list of abbreviations ( 38 pages), containing only one oversight: the seventeenth-century Spanish writer Gracian is listed under the name Baltasar. The book has thirty-three excellent illustrations depicting the author (including cartoons), the content of the novel, and the articles and notes. Perhaps the only thing missing here is authentic maps. There is a great deal of geography and topography in the novel, and the notes on these realities (especially those of St Petersburg) are among the most important and valuable. If the book had been provided with maps similar to those of the districts of old Moscow which adorn a recent publication of Matvey Komarov's lubok books [Комаров], one could not have wished for more.

The detailed abstract also deserves mention. All the book's components are presented and described with maximum accuracy. The only thing that confuses here is the apologetic exaggeration of the novel's virtues. It is difficult not to regret that advertising style has become an indispensable part of even the most academic of publications. Equally regrettable is that the print run is as small as 500 copies.

One of the paragraphs in the abstract traces a fifty-year "line of Gothic novels" in the "Literary Monuments" series. After the release of the first three such books in the late 1960s, there was an almost forty-year hiatus. The second "round" was issued in the 2000s: this book, together with the aforementioned edition of Gnedich, begins the third. Interest in mystical topics has never waned among the general readership; now academic publications are also paying increased attention to this field of literature.

\section{Список литературы}

Гнедич Н. Дон-Коррадо де Геррера. М. : Ладомир : Наука, 2019. 456 с.

Греч Н. Черная женщина. М. : Ладомир : Наука, 2020. 668 с.

Комаров М. Ванька Каин. Милорд Георг. М. : Ладомир : Наука, 2019. 440 с.

Литературная теория немецкого романтизма. Л. : Изд-во писателей, 1934. 333 с.

\section{References}

Berkovskii, N. Ya. (Ed.). (1934). Literaturnaya teoriya nemetskogo romantizma [Literary Theory of German Romanticism]. Leningrad, Izdatel'stvo pisatelei. 333 p.

Gnedich, N. (2019). Don-Corrado de Gerrera [Don-Corrado de Guerrera] / ed. by E. O. Larionova. Moscow, Ladomir, Nauka. 456 p.

Gretch, N. I. (2020). Chernaya zhenshchina [The Black Woman] / ed. by E. V. Markasova. Moscow, Ladomir, Nauka. 668 p.

Komarov, M. (2019). Van'ka Kain. Milord Georg [Vanka Cain. Milord Georg] / ed. by V. D. Rak. Moscow, Ladomir, Nauka. 440 p. 